\title{
Effects of Pesticide Treatments and Sowing Dates on Growth Parameters and Yield of Onion Plant (Allium Cepa L.)
}

\author{
Hassan A.I. Salem ${ }^{1}$
}

\begin{abstract}
Two field trials were conducted at the newly reclaimed sandy clay loam soil at El-Nubaria region - Alexandria Governorate, A.R.E. in the two successive growing seasons 2008/2009 and 2009/2010 to investigate the effect of three pesticides: insecticide (pirimiphos-methyl), fungicide (metalaxyl) and the herbicide (pendimethalin) combined with two sowing dates, early, mid-Nov. and late date $5^{\text {th }}$ Feb. on some growth characters: i.e., plant height, number of leaves/plant, fresh weight of leaves/plant, dry weight of leaves/plant, average weight of bulb and total yield of onion plant (Allium cepa L.) c.v. Giza 20. The recommended rates of these pesticides were individually applied.
\end{abstract}

The obtained results showed that all the studied parameters were significantly increased with the three pesticides, and pendimethalin was highly effective followed by metalaxyl while pirimiphos-methyl was the least effective. Total yield mean values were 22.40 and 22.68 ton/fed for pendimethalin and $\mathbf{1 8 . 9 6}$ and $\mathbf{1 9 . 1 4}$ ton/fed for metalaxyl and 10.06 and 10.70 ton/fed for pirimiphosmethyl compared with the control 8.32 and 8.64 ton/fed in the first and second seasons respectively.

All the studied parameters were increased in early sowing date, mid-Nov. compared with the late sowing date, $5^{\text {th }}$ Feb. in the two seasons.

The interactions between the three pesticides and the sowing date had a significant effect on: number of leaves/plant in the first season, fresh weight of leaves, dry weight of leaves, average weight of blub in the two seasons and total yield in the first season.

The highest values of all these parameters occurred on pendimethalin at early sowing date, mid-Nov.

Key words : hormesis - shikimate levels - growth stimulus - onion - responductive vegetative - blackgram.

\section{INTRODUCTION}

Onion (Allium cepa L.) is one of the important vegetable crops in Egypt for export and local consumption. Bulbs of the variety "Giza 20" are acceptable overseas but will receive more acceptance when their maturity and shipments are earlier (Abd ElRehim et al., 1997).

The population explosion has put tremendous pressures on farmers to grow more food and increase its quality. Therefore, farmers are resorting to more use of pesticides to increase production of food crops and to ensure the protection of harvest against diseases and pests. On the other hand, the great expansion of the use of pesticides resulted in pollution of the environment and creating adverse conditions for the life of mankind and his food. Therefore, it is essential to monitor pesticide residues in crops, especially vegetable crops, food and environment (Edrisha, 1982) and to study the bioprocesses that occurred in the plant in order to avoid the side effects and potential hazards of pesticides (Salem, 2004). Karungi et al. (2010) reported that carbofuran increase yield of pepper. Also, Vieira et al. (2010) indicated that fluazinon increase yield of common bean in Brazil. In addition, Fayed et al. (2002) demonstrated that pesticide and mechanical weed control treatments increased significantly the height, leaf area index (LAI), top and root fresh weight of sugar beet.

At present, effective control techniques other than insecticide application against the pests are not available. The crops growers use various insecticides to control the pests. Insecticidal control is not only expensive but also its residues on the sprayed surface of the crops or in the soil have become a matter of concern and environmental pollution (Prodhan et al., 2008). The indiscriminate use of pesticides causes phytotoxicity and destruction of beneficial organisms such as predators, parasitoids, microorganisms and pollinators (Luckman and Metcalf, 1978 and Hussain, 1984). Under these circumstances it becomes necessary to find out some eco-friendly alternative methods for insect pest's managemeat which include the manipulation of the cultural practices like deviating the date of sowing, mulching, intercropping, screening of genotypes in formulating the integrated pest management approach (Prodhan et al., 2008).

Sowing date factor is a reliable practical expression for the effect of climatic conditions on crop growth and productivity (Fayed et al., 2002). In this respect, Ali et al.(2009) demonstrated that early sowing of cotton plant showed the highest crop growth rate (CGR) and relative growth rate (RGR), and the reproductive vegetative ratio (RVR) on seed and large number of cotton bolls. Moreover, Prodhan et al. (2008) reported that the highest yield of blackgram was obtained from Aug.7 followed by Aug.14 and Aug.21, while Sept.4 and Sept.11 had the lowest effect. Also, Riad et al. (2002) showed that plant height, leaf area (LA), leaf area index

${ }^{1}$ Agric. Res. Center, Centeral Agric. Pest. Lab.,

Sabahia Exp. Station, Alexandria, Egypt.

Received April 2, 2012, Accepted April 26,, 2012 
(LAI), leaf fresh and dry weight/plant were appreciably increased on early planting (May) as compared with late planting (June) of pigeon pea plant. The use of agricultural manipulation (agricultural practicies, i.e. sowing date ... etc) along with pesticide might help in reducing the level of pest infestation and subsequantly increase plant yield (Fayed et al., 2002; Omar et al., 1994 and El-Shami et al., 1993).

The present work aimed to determine some growth parameters (i.e. plant height, numbers of leaves, fresh and dry weight, average weight of bulb) and total yield of onion sown in 2008/2009 and 2009/2010 seasons under different pesticide regimes and sowing dates in reclaimed agricultural soil at El-Nubaria region Alexandria Governorate, ARE.

\section{MATERIALS AND METHODS}

\section{Pesticides used:}

\section{1- Insecticide}

Pirimiphos-methyl (Actellic) 50\% EC: 0-2diethylamino $-6-$ methylpyrimidin $-4-$ yl-0,0dimethylphosphorothioate

Introduced by ICI Agrochemicals.

\section{2- Fungicide}

Metalaxyl (Ridomil plus) 50\% WP : N (2,6 dimethylphenyl) - N- (methoxyacetyl) - alanine methylester

Origin : Ciba - Giegy crop.

\section{3- Herbicide}

Pendimethalin (Stomp) 50\% $\quad$ EC : N- (1ethylpropyl)- 3,4- dimethyl - 2,6-dintrobenzenamine Introduced by American Cyanamid Co.

\section{Field experiment:}

Onion plant (Allium cepa L.), c.v. Giza 20 was used in this experiment, transplanting dates were either early $\left(15^{\text {th }}\right.$ November) or late $\left(5^{\text {th }}\right.$ February) during
$2008 / 2009$ season and the experiment was repeated during 2009/2010 season. The fungicide was sprayed after 45 days after planting according to the recommended rate $250 \mathrm{~g} / \mathrm{fed}$. with $100 \mathrm{~L}$. water. For insecticide, 40 days after planting the plants were sprayed with the insecticide according to the recommended rate $500 \mathrm{~cm}^{3} /$ fed with $100 \mathrm{~L}$. water. The herbicide was sprayed before transplanting on the prepared soil, the herbicide was incorporated into the soil, then the soil were irrigated and seeds were sown after soil was dried, the herbicide was applied at its recommended rate $1.7 \mathrm{~L}$./fed. The pesticides were applied using a knapsack sprayer equipped with one nozzle. The treatments were designed in complete randomized plots with three replicates, each of $1 / 100$ of feddan. The experiments were conducted at the reclaimed agriculture soil at El-Nubaria - region, Alexandria Governorate, A.R.E. Soil was sandy clay loam [ sand $53.47 \%$, silt $17.12 \%$, clay $29.40 \%$, pH 8.2 , $\mathrm{CaCo}_{3}$ 26.15\% (Page et al., 1982)]. Normal agricultural practices were followed.

Average monthly meteorological data for Nubaria region Alexandria Governorate during seasons 2008/2009 and 2009/2010 were tabulated in table (1).

\section{Plant samples:}

After 100 days from transplanting, samples of onion plant were taken to evaluate: plant height, number of leaves, fresh and dry weight of leaves.

Harvest took place at the end of the season after 150 days from transplanting, total yield (ton/fed.) and average weight (gram) of bulb was measured.

\section{Statistical analysis:}

The obtained data were statistically analyzed according to Steel and Torrie (1980).

Table 1. Average monthly meteorological data for El-Nubaria region, Alexandria Governorate, A.R.E.

\begin{tabular}{|c|c|c|c|c|c|c|c|c|}
\hline \multirow{2}{*}{ Item } & \multicolumn{4}{|c|}{ Season 2008/2009 } & \multicolumn{4}{|c|}{ Season $2009 / 2010$} \\
\hline & Nov. & Dec. & Jan. & Feb. & Nov. & Dec. & Jan. & Feb. \\
\hline Mean max. temp. $\left(\mathrm{C}^{0}\right)$ & 23.1 & 19.0 & 19.2 & 17.2 & 21.9 & 19.9 & 20.2 & 19.7 \\
\hline Mean min. temp. $\left(\mathrm{C}^{\mathrm{o}}\right)$ & 18.0 & 14.4 & 13.6 & 11.7 & 17.5 & 15.0 & 14.5 & 13.3 \\
\hline Mean max. RH *\% & 76.2 & 76.7 & 73.9 & 67.1 & 76.4 & 73.7 & 77.1 & 68.3 \\
\hline Mean min. RH \% & 52.5 & 55.4 & 50.8 & 43.2 & 54.8 & 51.2 & 54.0 & 44.5 \\
\hline AVG. W.S. $(\mathrm{m} / \mathrm{s})^{* *}$ & 7.3 & 8.0 & 8.5 & 9.3 & 6.8 & 9.1 & 8.7 & 8.4 \\
\hline AVG Soil temp. $(10 \mathrm{~cm})$ & 21.4 & 17.5 & 16.8 & 14.9 & 19.9 & 17.7 & 17.7 & 16.9 \\
\hline
\end{tabular}

* $\mathrm{RH}=$ Relative humidity.

** AVG. W.S. (m/s) = Average weed speed (meter/second).

Source: (1) Ministry of Agriculture - Agricultural Research Center - Centeral Laboratory for Agricultural Climate.

(2) Ministry of Agriculture - Agricultural Research Center - Centeral Adminstration of Agricultural Extension. 


\section{RESULTS AND DISCUSSION}

Effect of pesticide treatments and sowing dates and their interactions on growth parameters and yield of onion plant:

\section{I- Effect of pesticide treatments}

Results in tables (2 to 4) showed that all applied pesticide treatments increased significantly plant height, number of leaves, fresh and dry weight of leaves, average weight of bulb as well as total yield than the control in the two seasons. Comparing the results between the pesticide treatments indicated that pendimethalin was highly effective followed by metalaxyl while pirimiphos-methyl was the least effective (tables 2 to 4 ) in this respect. For plant height mean values were 80.00 and $81.50 \mathrm{~cm}$ for pirimiphosmethyl; and 86.50 and $88.00 \mathrm{~cm}$ for metalaxyl; and 92.50 and $93.50 \mathrm{~cm}$ for pendimethalin compared with the control 72.50 and $73.50 \mathrm{~cm}$ for the first and second season, respectively (table 2). Similary, Karungi et al. (2010) reported that carbofuran increase yield of pepper. Also, Vieira et al. (2010) indicated that fluazinon increase the yield of common bean in Brazil. In addition, Obonyo et al. (2008) showed that sorghum yield increase through the mainpulation management practices such as genotype, selection, fertilizer and insecticide application. Also, Fayed et al. (2002) demonstrated that pesticide and mechanical weed control treatments increased significantly the height, leaf area index (LAI), top and root fresh weight of sugar beet. Moreover, Abdel Razik et al. (1991) showed that butralin, pendimethalin and dinitramine had stimulating effect on plant height, fresh weight and yield of spinach.

These results may be due to insecticide lowered population of insect on crop to varying extents and increased yield (Karungi et al., 2010). These results may be attributed to that the pesticide stimulate the growth of a range of plant species, as measured in several plant organs. This hormesis effect is likely to be related to the molecular of pesticide, science the effect was not seen in pesticide - resistant plants, and shikimate level were enhanced in plants with stimulated growth (Velini et al., 2008). These results may be attribated to the increase in number of healthy plants, in addition pesticides have been useful in many situation in obtaining significantly higher yield through the control of plant pests and diseases (Sinclair, 1979 and Omar \& Rahhol, 1993). This may be due to the absence of weeds competition with the host plants (Blackshow et al., 1981; Nelson \& Thoreson, 1981; Nelson \& Giles, 1989; Habib et al., 1989 and Sabra et al., 1999).

\section{2- Effect of sowing dates}

Data revealed higher values of early sowing date, mid-Nov. planting for plant height, number of leaves, fresh and dry weight of leaves, average weight of bulb and total yield compared with $5^{\text {th }}$ Feb. (tables 2 to 4 ). For plant height, general means in table (2) for pirimiphos-methyl, metalaxyl and pendimethalin in the first season were 84.50 and $81.25 \mathrm{~cm}$ for early and late sowing date, respectively; and in the second season were 85.75 and $82.50 \mathrm{~cm}$ for early and late sowing date, respectively. For total yield, general means in table (4) for pirimiphos-methyl, metalaxyl and pendimethalin in the first season were 15.73 and 14.13 ton/fed for early and late date, respectively; and in the second season were 16.17 and 14.50 ton/fed for early and late date, respectively. Similar results were obtained by Harrison et al. (2011), who showed that early sowing date increased growth and yield of maize. Also, Ibrahim and Adesiyun (2009) found that Thrips tabaci is the major insect pest of onion in sokota state (in Nigeria) as reported world wide and that the pest can be effectively managed by early planting / transplanting with bulb yields of up to $48 \mathrm{t} / \mathrm{ha}$ in the early transplanting (November), while delayed planting (February) $5.5 \mathrm{t} / \mathrm{ha}$ and (March) 1.5 t/ha. In addition, Ali et al. (2009) demonstrated that early sowing of cotton plant showed the highest crop growth rate (CGR) and relative growth rate (RGR), and the reproductive vegetative ratio (RVR) on seed and large number of cotton bolls. Moreover, Prodhan et al. (2008) reported that the highest yield of blackgram was obtained from Aug.7 followed by Aug.14 and Aug.21, while Sept.4 and Sept.11 had the lowest. Also, Riad et al. (2002) showed that plant height, leaf area (LA), leaf area index (LAI), leaf fresh and dry weight/plant were appreciably increased on early planting (May) as compared with late planting (June) of pigeon pea plant.

Also, Ibrahim (1982) studied the effects of four transplanting dates in Egypt during (October, November, December and January) on vegetative growth characters of lettuce plants, using the two cultivars Dark Green and Balady. The obtained results illustrated clearly that the nine characters of plant fresh weight, leaves fresh weight, plant diameter, leaf area, plant height, stem length, plant dry weight, leaves dry weight and total yield were increased significantly by transplanting on December 22; compared with January 16. On the other hand, late transplanting (on January 16) increased the two characters stems fresh weight and stem/leaves percentages. The number of leaves per plant was insignificantly affected by the transplanting dates of December 22 and January 16. Finally, the effects of 
four treatments of air temperature $\left(10,14,18\right.$ and $\left.22^{\circ} \mathrm{C}\right)$ on relative growth rates of six different lettuce cultivars were studied by Scaife (1973). The results illustrated that the relative growth rate and dry - matter content were increased with increasing the air temperature between 10 and $18^{\circ} \mathrm{C}$. The relationship between the logarithm of the relative growth rate and air temperature was almost exactly linear. Whereas, behyond $18^{\circ} \mathrm{C}$ the increase in relative growth rate was more gradual. The optimum temperature was propably above the highest used degree $\left(22^{\circ} \mathrm{C}\right)$ in the experiment.

This finding showed that the promotive influence of early sowing date might have been due to the prevailling climatic conditions (table 1) during early planting that favored the production of healthy tall plants having greater number and larges leaves and consequently led to higher assemilation and larger fresh and dry weight of plant and increased total yield compared with late planting.

Meteorological data in table (1) showed that during January and February, soil temperature decreased to reach its average $\left(14.9^{\circ} \mathrm{C}\right)$ in February $2008 / 2009$. The relative humidity $(\mathrm{RH} \%)$ reach its maximum $(77.1 \%)$ in January 2009/2010. Such cooler and humidity weather conditions favor the germination and establishment of many new flushes of weed and in turn increased the weed infestation of onion field. Unfortunately, this time coincided with the emergence and seedling development of lately planting date $\left(5^{\text {th }}\right.$ February planting). Herein, a severe competition anticipated between the lately planting onion and their analogeous emerged weed flush plants. This exactly exegetics the correlation between the late planting date, increases in weed abundance and final reduction in onion yield. Confirmid results in this respect were reported by Harrison et al. (2011) who demonstrated that early season temperature increases have caused the maize reproductive period to start earlier and increased growth and yield of maize. Also, Ibrahim and Adesiyun (2009) reported that the peak of thrips incidence in the various transplanting of onion plant were as follows: November at 15 (week after transplanting) WAT (120), December at 12.5 WAT (234), January at 9.5 WAT (373), February at 8.5 WAT (217), March at 6 WAT (41.2) and April at 5 WAT (20). Onion bulb yields were also found to differ in descending order as follows: November (48 t/ha), December (42 t/ha), January (13.5 t/ha), February (5.5 t/ha) and March (1.5 t/ha). These results also may attributed to early sowing date resulted in higher translocation and mobilization of photosynthates which were utilized in production high yield of plant (Ali et al., 2009). These also may be due to that early planting gave lower infestation of major insect pests and late plantings showed higher infestation (except thrips). Crop under early plantings received more rainfall than late plantings. Insect movement and egg deposition probably hampered due to rainfall. For this reason infestations were lower at earlier plants compared to late plantings (Prodhan et al., 2008). These results are in conformly with those of Nderitu et al. (1990) and Prodhan (2007). Nderitu et al. (1990) reported that the numbers of leaf punctures, eggs, larvae and puparia of stemfly were higher in late than early planted of bean crop and the crop planted date in the second was severely damaged due to generally higher population levels which had been building up in the course of the season. Prodhan (2007) showed that early planting (up to 21 August) gave lower infestation of stemfly than late planting of blackgram plant which known as mashkalai, urdbean or blackbean belongs to the family leguminosae which is the fourth most important pulses in Bangladesh. In addition Fayed et al. (2002) indicated that cooler and humid weather conditions on lately planting date $\left(5^{\text {th }}\right.$ planting) favor the germination and establishment of many new flushes of weeds and in turn increased infestation of sugar beet field. These also may be due to the unconvenient environment conditions in particulary the low temperature and/or the day length throughout the vegetative growth stage which in turn affect the reproductive growth and yield crop (El-Deeb et al., 1994). Also, Wanger and Spira (1994) showed that weed seedling emergence was stimulated followed the first substantial autumn rains.

\section{3- Effect of interaction}

Data in the interaction between the main factors under study were divided into significant and insignificant effects. In this respect, it has to be mentioned that the insignificant interactions were excluded and this implies that each factor acts independently. The significant interactions will only be discussed.

Pesticide treatment $\mathrm{X}$ sowing date interactions had a significant effect on certain growth characters and total yield under study. Such effect was true in the first season, other was in the second one and other in the two seasons. The interaction between the three pesticide treatments and sowing date had a significant effect on number of leaves and total yield in the first season only (tables 2 and 4). The interaction between the three pesticide treatments and sowing dates did not affect the plant height in the two seasons.

Results of the interaction had a significant effect of the three pesticides on fresh weight of leaves, dry weight of leaves and average weight of bulb in the two seasons (tables 3 and 4). A speculative view to results of the 


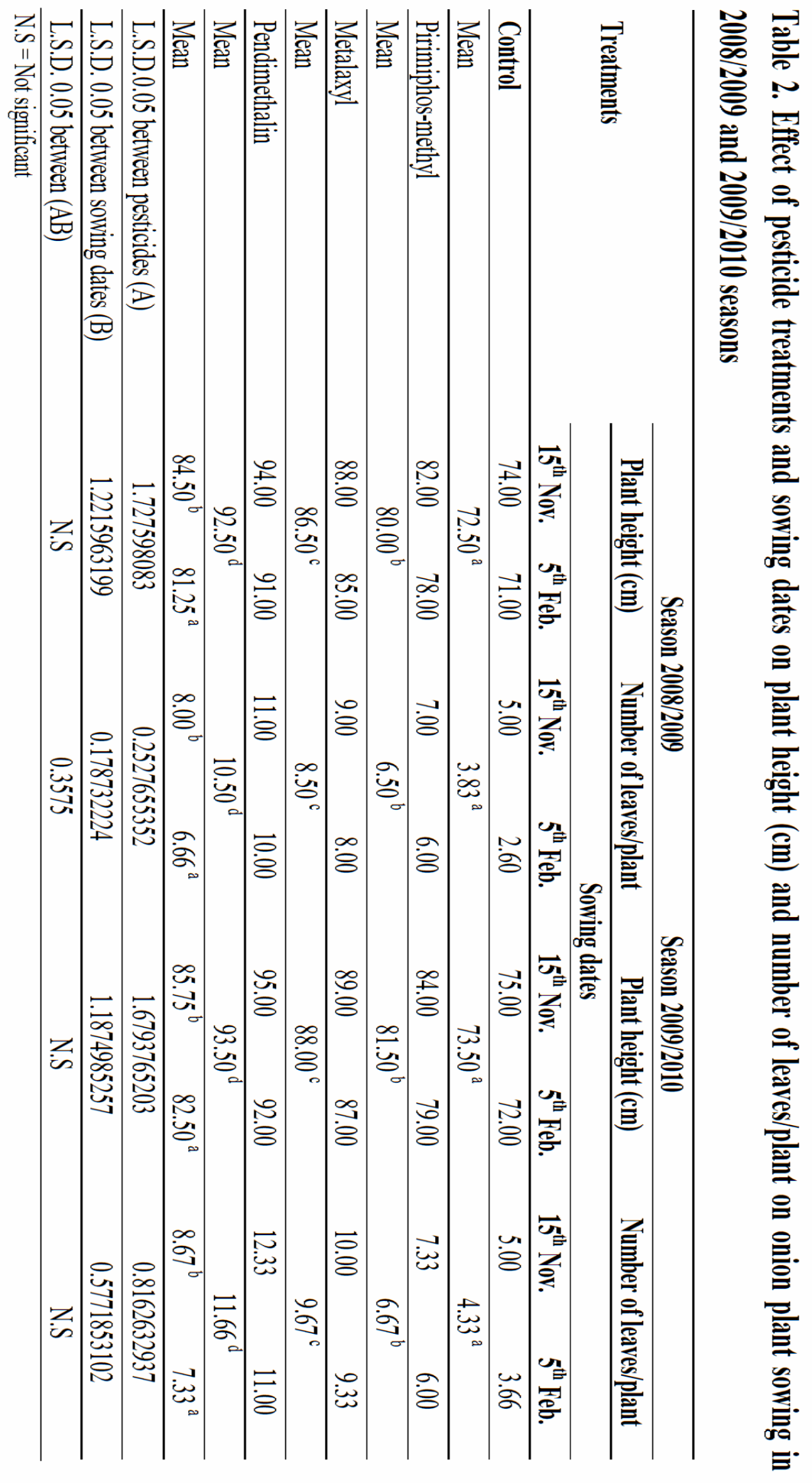




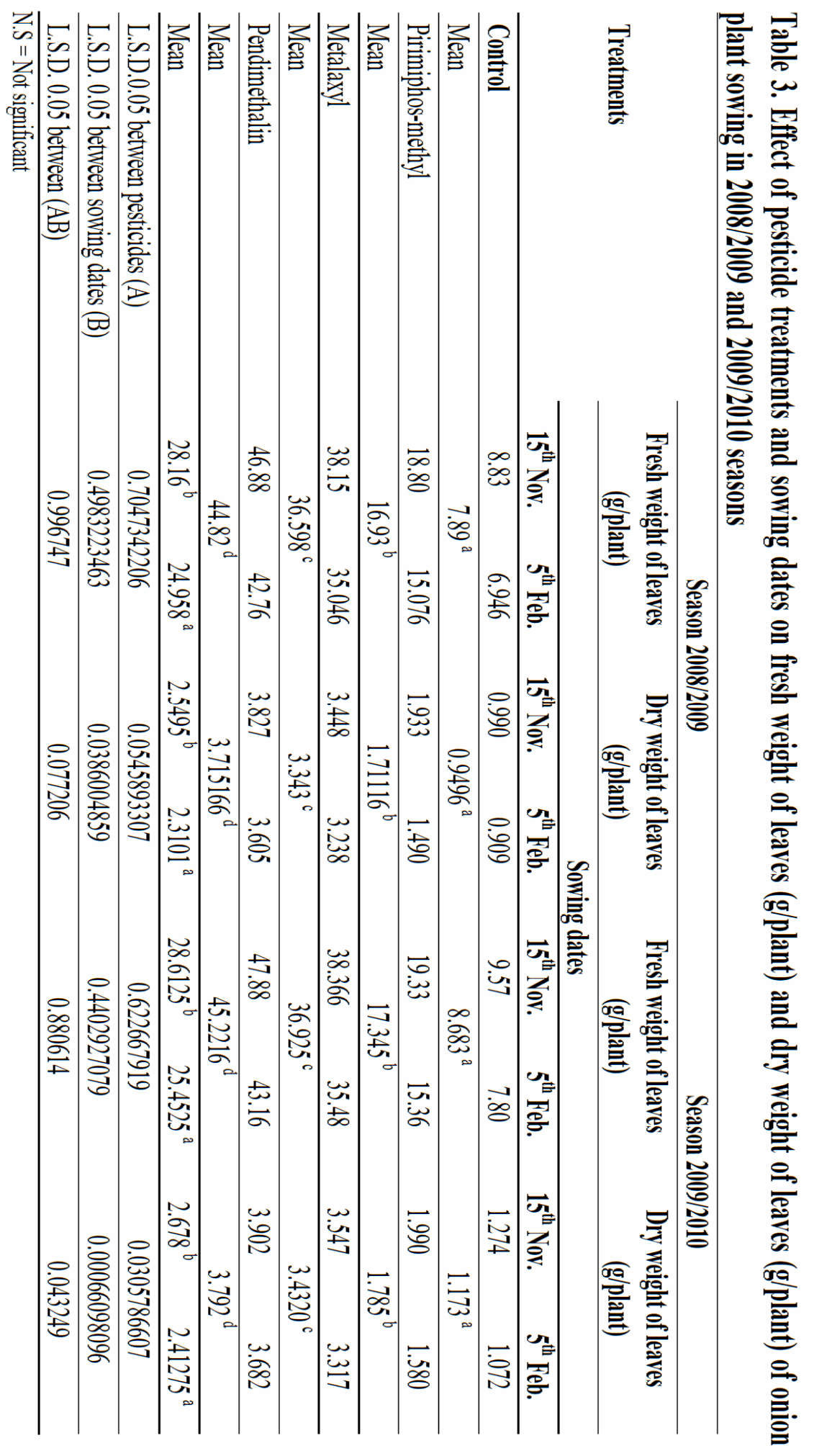




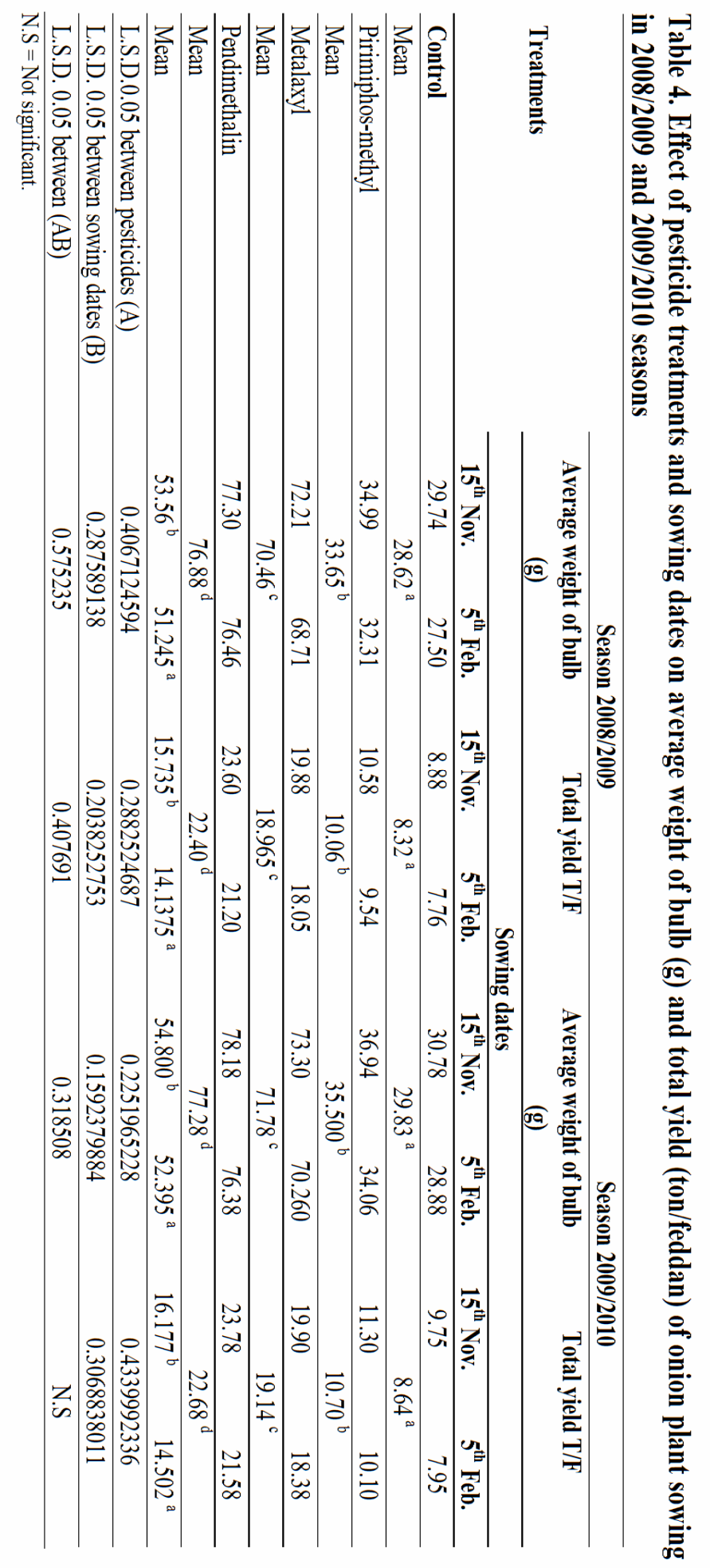


interaction deduce that significant increases in all growth parameters and yield were occurred on pendimethalin treatment and early sowing date midNov. Otherwise, the lowest values were obtained from untreated plants at the late date $5^{\text {th }} \mathrm{Feb}$.

The efficency of pesticide treatments which was influenced by the date of planting might be due to the effect of prevailing temperatures (table 1) on the absorption and translocation of the pesticide in plants (Edgington and Peterson, 1977 and El-Shami et al., 1993).

From the collective data, it is obviously clear that pendimethalin was the highly effective pesticide followed by metalaxyl, while pirimiphos-methyl were the lowest one and early sowing date mid-Nov., was more effective than late sowing date $5^{\text {th }}$ Feb. on increasing growth parameters and yield of onion plant.

Accordingly, it can be concluded that planting onion plants on early sowing date (mid-Nov.) with pendimethalin treated may be recommended for the best growth and yield under environmental canditions of ElNubaria region Alexandria Governorate.

In conclusion, the use of chemical control and/or agricultural practicies, i.e., sowing date were maximized to increase growth characters and yield of crops in attempt to minimize chemical control pesticides hazards, while maintaining increased yield production.

\section{REFERENCES}

Abdel-Razik, A.H. Soliman; A.H. Mansy and S.T. El-Deep (1991). Effects of seeds rate and some herbicides on spinach production and weed cotrol. Alex. J. Agric. Res. 36 (1): 31-45.

Abd El-Rehim, G.H.; F.A. Ahmed; G.I. Shalaby and A.A. Waly (1997). Effect of transplanting date and density of bulb yield and quality of Giza 20 onion in upper Egypt. Egypt J. Agric. Res., 75 (3): 681-695.

Ali, H.; M.N. Afzal and D. Muhammad (2009). Effect of sowing dates and plant spacing on growth and dry matter partitioning in cotton (Gossypium hirsutum L.). Pak. J. Bot., 41 (5): 2145-2155.

Blackshaw, R.E.; E.H. Stobbe and A.R.W. Sturko (1981). Effect of seedling dates and densities of green foxtail (Staria viridis) on the growth and productivity of spring wheat (Triticum aestivum). Weed Sci., 29: 212-217.

Edgington, L.V. and C.V. Peterson (1977). Systemic fungicides theory uptake and translocation. In, M.K. Siegel and H.D. Sisler (eds.) Antifungal Compounds, Vol.11. M. Dekken, New York. pp. 57-89.

Edrisha, M.M.S. (1982). Studies on some pesticides used on vegetable crops. M.Sc. Thesis, Faculty of Agriculture, Alexandria University, A.R.E.
El-Deeb, S.M.A.; A.A. Sadek and A.A. Zayed (1994). Effect of sowing date on the growth, yield and volatile oil of Carum carvi L. plants. Egypt. J. Agric. Res., 72 (4): 10751086.

El-Shami, M.A.; N.G.H. Awad and N.A.R. Abdel-Nour (1993). Effect of fungicides and herbicides interactions on tomato damping-off and plant growth. Egypt. J. Agric. Res., 71 (3): 641-658.

Fayed, T.B.; L.H. El-Geddawy; A.A. Abdel Gawad and A.M. Abd El-Aal (2002). Abundance of weeds and efficiency of weed control programs in sugarbeet fields in relation to planting date. The first Conf. of the central Agric. Pesticide Lab., 3-5 Sep. (2): 898-916.

Habib, S.A.; A.A. Al-Souonbil; K.W. Ibadi and I. George (1989). Response of potatoes (Solanum tuberosum) and weeds to herbicides. Arab. J. of Plant Prot., 7 (1): 56-63.

Harrison, L.; J. Michaelsen; C. Funk and G. Husak (2011). Effects of temperature changes on maize production in Mozambique. Climate Research, 48: 211-222.

Hussain, M. (1984). Controlling rice borers under Bungladesh conditions. Pestology, 8 (8): 28.

Ibrahim, F.I.M. (1982). Effect of transplanting date on fresh yield and weed production of lettuce crop. M.Sc. Thesis. Fac. Agric., Tanta Univ., A.R.E.

Ibrahim, N.D. and A.A. Adesiyun (2009). Effects of staggered planting dates on the control of Thrips tabaci lindeman and yield of onion in Nigeria. African Journal of Agricultural Research. 4 (1): 033-039.

Karungi CL, J.; P. Agamire; J. Kovach and S. Kyamanywa (2010). Cover cropping and novel pesticide usage in the management of pests of hot pepper (Capsicum chinese). International Journal of tropical insect science. Vol.30, issue 02 pp. 84-92.

Luckman, W.H. and R.L. Metcalf (1978). The pest management concept. In: Introduction to insect pest Management. John Willey and Sons, New York, pp. 3-35.

Nderitu, J.H.; H.Y. Kayumbo and J.M. Mueke (1990). Effect of date of sowing on beanfly infestation of the bean crop. Insect Sci. Appli., 11 (1): 97-101.

Nelson, D.C. and I.F. Giles (1989). Weed management in two potato (Solanum tuberosum) cultivars using tillage and pendimethalin. Weed Sci., 37 (2): 228-232.

Nelson, D.C. and M.C. Thoreson (1981). Competition between potatoes (Solanum tuberosum) and Weeds Sci., 29: 672-677.

Obonyo, D.N.; J.B. Ogola; A.W. Kamau (2008). Effects of time of planting, fertilizer and insecticide on sorghum shoot fly, Atherigona soccata (Dipetra; Muscidae), on two varieties of sorghum. African Entomology 16 (2): 185195.

Omar, S.A.M.; D.E. Salem and S.M.M. El-Gantiry (1994). Effect of some fungicides, sowing date and seed rate on the incidence of root rot/wilt disease complex and yield of sugar crop. Egypt. J. Agric. Res., 72 (1): 59-67. 
Omar, S.A.M. and M.M.H. Rahhal (1993). Influence of fungicides on damping of disease and seed yield of soybean. Egypt. J. Agric. Res., 71 (1): 65-74.

Page, A.L.; R.H. Miller and D.R. Keeney (eds.) (1982). Methods of soil analysis. Part 1\&2 American Society of Agronomy, madison, WI.

Prodhan, M.Z.H. (2007). Bioecology and management of stemfly, Ophiomyia phaseoli (Tryon) (Diptera;Agromyzidae) on blackgram. Ph.D. Thesis. Department of Entomology, Bangladesh Agricultural University, Mymensingh. 115p.

Prodhan, M.Z.H.; Hossain M.A.; Rahman M.T.; Afroze F. and Sarker M.A. (2008). Incidence of major insect pests of blackgram at different dates of sowing. Int. J. Sustain. Crop Prod. 3 (3): 6-9.

Riad, M.S.; N.A. Nour El-Din; H.M. Abd El-Aziz and A.A. El-Houssini (2002). Growth response of pigeon pea (Cajanus cajan) plants to phosphorus application, sowing time and clipping height. Pro. Minia $1^{\text {st }}$ Conf. for Agric. \& Environ.. Sci., Minia, Egypt, March 25-28, pp.1509-1523.

Sabra, F.S.I.; F.A. Kassem and M.A.S. Khalifa (1999). Effectiveness of herbicidal treatments against weeds in wheat and their action on yield and yield components. J. Pest. Cont. \& Eniron. Sci., 7 (3): 103-121.
Salem, H.A.I. (2004). Performance of spinach plants (Spinacia oleracea, L.) under different pesticides and sowing dates. Alex. Sci. Exch., 25 (3): 585-604.

Scaife, M.A. (1973). The early relative growth rates of six lettuce cultivars as affected by temperature. Ann. Appl. Biol. 74 (1): 119-128.

Sinclair, J.B. (1979). Soybean seed pathology. In: J.T. Yorinori; J.B. Sinclair; Y.R. Mehta and S.K. Mogan, seed pathology progress. Pub. Fundacao instituto Agronomic Do, Parana- IAPAR, pp.161-171.

Steel, R.G.D. and J.H. Torrie (1980). Principles and procedures of statistic. A biometrical approch. $2^{\text {nd }} \mathrm{Ed} ., \mathrm{Mc}$ Graw-Hill Kogahusha- Ltd. P.633.

Velini, E.D.; E. Alves; M.C. Godoy; D.K. Meschede; R.T. Souza and S.O. Duke (2008). Glyphosate applied at low doses can stimulate plant. Pest Management Science, Vol.64 issue 4, pp. 489-496.

Vieira, R.F.; T.J. Paula Junior and H. Teixeira (2010). White mold management in common bean by increasing withinrow distance between plants. Plant disease, 94 (3): 361367.

Wanger, L.K. and T.P. Spira (1994). Germination, recruitment and survival in the weedy annual Medicago polymorpha in successive wet and dry years. Americ. Midland Naturalist. 131 (1): 98-108. (C.F. CAB Absts. 1996). 


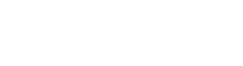

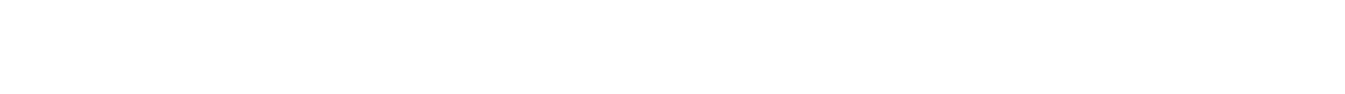

\section{(Allium cepa L.)}

Pسن عبد العزيز إيراهيمساح

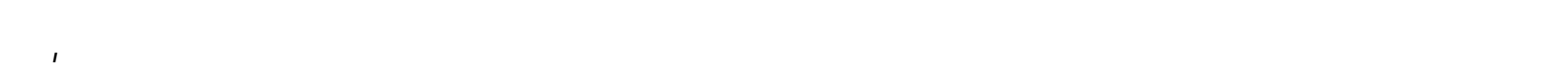

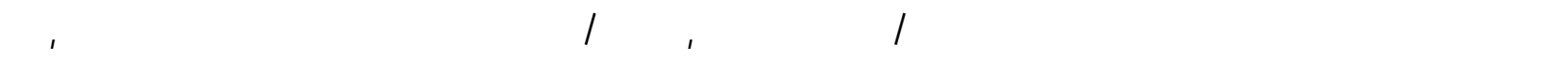

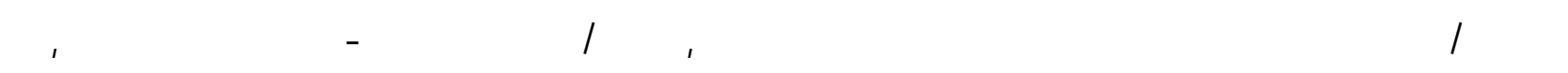

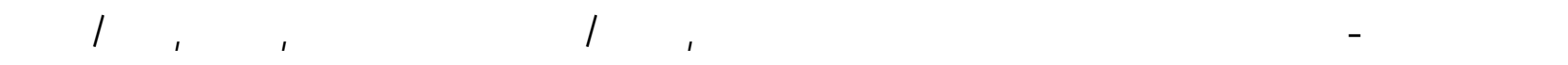

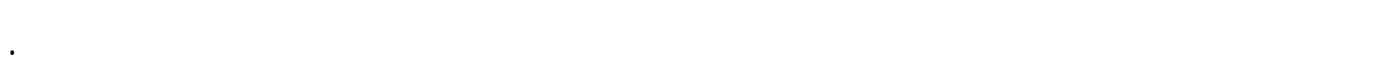

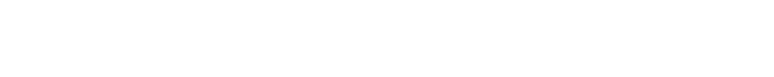

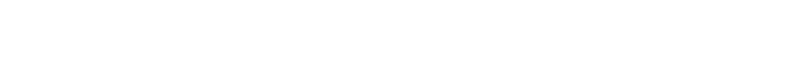

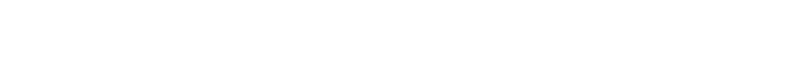

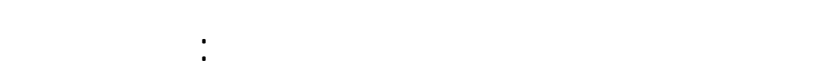

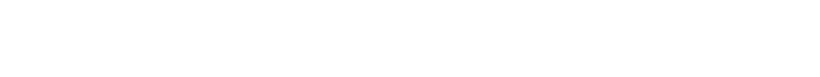

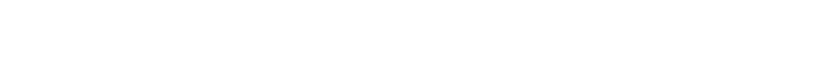

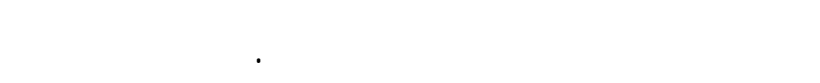

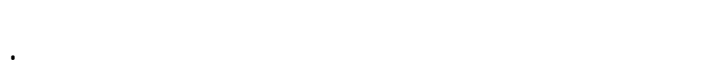

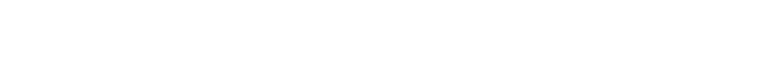

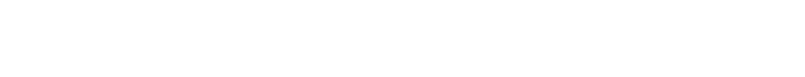

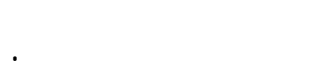

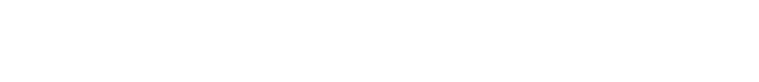

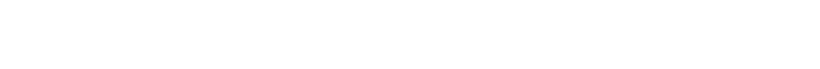

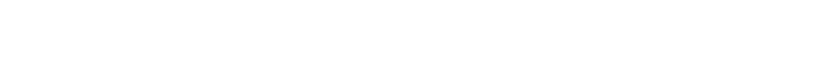
مع الهفظا على زيادة الإتناج.

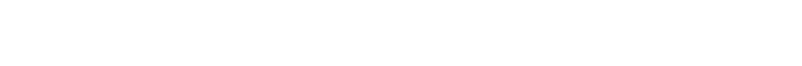

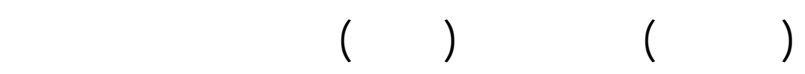

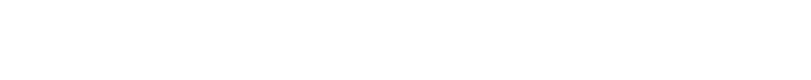

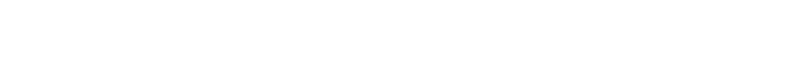

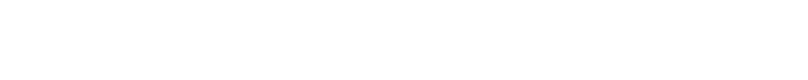

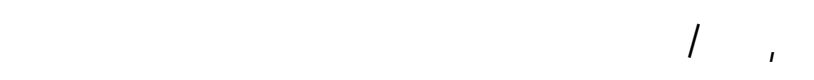
صميم التطاعلت العشوائة الكملة المانة Randamized Complete Block Design (RCBD) من ثلاة مكررات.

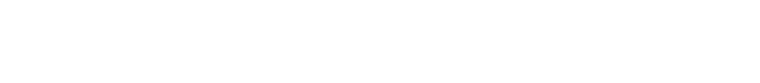

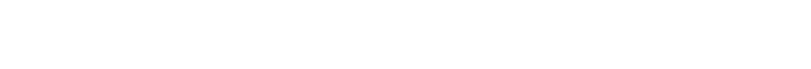

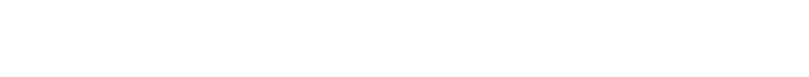

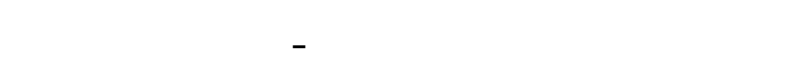

